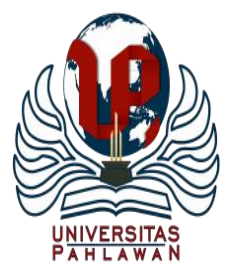

Edukatif : Jurnal Ilmu Pendidikan Volume 3 Nomor 6 Tahun 2021 Halm 3520 - 3530

EDUKATIF: JURNAL ILMU PENDIDIKAN

Research \& Learning in Education

https://edukatif.org/index.php/edukatif/index

\title{
Pengembangan Tes Kinerja pada Materi Teks Negosiasi dan Teks Debat Mata Pelajaran Indonesia Berbasis Konteks Budaya Lokal Sumatera Barat
}

\author{
Wilda Fathia \\ Institut Agama Islam Negeri Batusangkar, Indonesia \\ E-mail : wildafathia@iainbatusangkar.ac.id
}

\begin{abstract}
Abstrak
Permasalahan yang sering muncul dalam pembelajaran menulis teks adalah penggunaan tes kinerja yang tidak tepat, sehingga diperlukan instrumen tes kinerja yang tepat. Tes kinerja yang dikembangkan berbasis konteks budaya lokal (Sumatera Barat). Tujuan penelitian ini adalah untuk mengembangkan tes kinerja teks negosiasi dan teks debat yang valid, praktis, dan efektif. Jenis penelitian ini adalah penelitian pengembangan atau research and development. Model pengembangan penelitian mengacu pada model pengembangan Plomp yang terdiri atas tiga tahap pengembangan, yaitu penelitian pendahuluan, fase prototyping, dan fase penilaian. Hasil penelitian menunjukkan bahwa tes kinerja menulis teks negosiasi dan teks debat menggunakan konteks budaya Sumatera Barat siswa kelas X SMA untuk aspek isi validitas tes kinerja untuk aspek isi adalah 87,54\%, dengan kategori sangat valid. Kedua, tes kinerja menulis teks negosiasi dan teks debat menggunakan konteks budaya Sumatera Barat siswa kelas X SMA untuk aspek kebahasaan validitas tes kinerja untuk aspek bahasa adalah 82, 28 dengan kategori sangat valid. Ketiga, tes kinerja menulis teks negosiasi dan debat berkategori praktis, dengan hasil 77,25\%. Dengan demikian, tes kinerja berbasis budaya lokal dapat digunakan untuk dalam pembelajaran keterampilan menulis di tingkat menengah atas.
\end{abstract}

Kata Kunci: pengembangan, tes kinerja, teks negosiasi, teks debat, budaya lokal.

\begin{abstract}
The problem that often arises in learning to write texts is the use of inappropriate performance tests, so the right performance test instrument is needed. The performance test developed is based on the local cultural context (West Sumatra). The purpose of this research is to develop a valid, practical, and effective performance test of negotiating and debating texts. This type of research is research and development. The research development model refers to the Plomp development model which consists of three development stages, namely preliminary research, prototyping phase, and assessment phase. The results showed that the performance test of writing negotiation and debate texts using the cultural context of West Sumatra class X SMA students for the content aspect of the performance test validity for the content aspect was $87.54 \%$, with a very valid category. Second, the performance test of writing negotiation texts and debate texts using the cultural context of West Sumatran class X SMA students for the linguistic aspect, the validity of the performance test for the language aspect is 82, 28 with a very valid category. Third, the performance test for writing negotiation and debate texts is in the practical category, with a result of $77.25 \%$. Thus, performance tests based on local culture can be used for learning writing skills at the upper secondary level.
\end{abstract}

Keywords: development, performance test, negotiation text, debate text, local culture.

Copyright (c) 2021 Wilda fathia

$\triangle$ Corresponding author

Email : wildafathia@iainbatusangkar.ac.id

DOI : https://doi.org/10.31004/edukatif.v3i6.927

ISSN 2656-8063 (Media Cetak)

ISSN 2656-8071 (Media Online) 
3521 Pengembangan Tes Kinerja pada Materi Teks Negosiasi dan Teks Debat Mata Pelajaran Indonesia Berbasis Konteks Budaya Lokal Sumatera Barat - Wilda Fathia

DOI : https://doi.org/10.31004/edukatif.v3i6.927

\section{PENDAHULUAN}

Pembelajaran bahasa Indonesia merupakan pembelajaran yang kompleks. Ada tiga jenis tagihan keterampilan yang harus dikerjakan siswa dalam pembelajaran bahasa, yaitu keterampilan menyimak, berbicara, membaca, dan menulis (Mahsun, 2014). Salah satu penilaian keterampilan yang perlu mendapat perhatian khusus dari pendidik adalah keterampilan. Sebab, semenjak diterapkannya Kurikulum 2013, pembelajaran bahasa Indonesia di sekolah dilaksanakan berorientasi pada teks (Kemendikbud, 2015b). Dengan demikian, siswa perlu memahami berbagai teks dan menulis teks sesuai dengan tujuan pembelajaran.

Pembelajaran keterampilan menulis dianggap sebagai pembelajaran keterampilan yang lebih sulit dibandingkan dengan keterampilan berbahasa lainnya. Dengan demikian, penting bagi setiap pendidik terutama guru bahasa untuk dapat menyusun bahan ajar yang sesuai (Cicilia \& Nursalim, 2019). Selain itu, juga penting bagi pendidik untuk memperhatikan jenis tes yang diberikan kepada siswa. Salah satu jenis tes yang harus dikerjakan siswa pada pembelajaran bahasa Indonesia adalah tes kinerja. Tes kinerja merupakan satu jenis tes yang digunakan untuk mengukur keterampilan siswa dan termasuk pada ranah penilaian psikomotor (Ambarsari et al., 2017).

Pada Kurikulum 2013, terdapat berbagai teks yang dipelajari oleh siswa, mulai dari tingkat SD, SMP, dan SMA. Untuk tingkat SMA kelas X ada delapan teks yang dipelajari oleh siswa, baik pembelajaran bahasa maupun sastra (Mahsun, 2014). Beberapa teks yang dipelajari, yaitu teks negosiasi dan teks debat (Kemendikbud, 2015a). Negosiasi ialah proses tawar menawar dengan jalan berunding guna mencapai kesepakatan bersama antara satu pihak (kelompok atau organisasi) dan pihak (kelompok atau organisasi) lain (Kemendikbud, 2015:149-150). Sementara itu, debat adalah proses saling bertukar pendapat untuk membahas suatu isu dengan masing-masing pihak yang berdebat memberi alasan. Hasil debat menghasilkan sudut pandang baru yang bisa diterima kedua belah pihak (Kemendikbud, 2015). Dengan demikian, siswa dituntut untuk terampil menulis teks negosiasi dan debat dengan baik.

Kemudian, untuk memperoleh penilaian keterampilan menulis yang objektif, dibutuhkan instrumen tes kinerja yang baik. Oleh karena itu, pengembangan tes kinerja perlu dilakukan (Tosun, 2020). Sebab, instrumen merupakan salah satu unsur penting dalam proses penilaian (Rahmawan et al., 2016). Dengan demikian, instrumen yang baik diharapkan dapat memberikan kontribusi yang baik dalam proses pembelajaran. Pendidik perlu memahami dan memiliki instrupen penilaian yang sesuai dan akuran dalam menilai aktivitas, sikap, serta tugas siswa (Kurniawati \& Mawardi, 2021).

Fakta di lapangan menunjukkan bahwa terdapat beberapa kendala ketika siswa menulis sebuah teks. Salah satu permasalahan yang muncul adalah penggunaan tes kinerja yang tidak tepat (Merlis, 2017). Pada umumnya, pendidik cenderung memberikan tes esai dan melakukan penilaian secara subjektif tanpa menggunakan rubrik penilaian. Sementara itu, penilaian kinerja harus memiliki rubrik yang jelas. Permasalahan lain instrumen penilaian yang digunakan belum valid (Ambarsari et al., 2017). Selain masalah penilaian, masih terdapat permasalahan lain, yaitu guru hanya menggunakan tes untuk keterampilan menulis berdasarkan buku teks. Hal ini juga didukung oleh wawancara yang dilakukan dengan guru bahasa Indonesia di kota Padang, bahwa guru jarang menggunakan tes kinerja yang lengkap untuk memberikan tes kepada siswa. Permasalahan tersebut menyebabkan hasil tes menulis siswa tidak sesui dengan kriteria.

Selain hal tersebut, permasalahan lain yang ditemukan di lapangan di antaranya guru belum menggunakan tes kinerja yang lengkap dan disertai dengan instrumen penilaian. Kemudian, soal-soal bahasa Indonesia yang menggunakan konteks pengerjaan tugas juga belum digunakan guru. Padahal, sebaiknya guru menggunakan tes kinerja disertai dengan konteks dan instruksi yang lengkap, sehingga dapat memberikan kemudahan bagi siswa dalam mengerjakan tes. Selain itu, guru juga jarang menggunakan rubrik penilaian dalam menilai. Jadi, rubrik tersebut penting bagi siswa dan guru. Hal ini sesuai dengan teori yang dikemukakan Atmazaki (2013) bahwa rubrik tidak saja untuk meyekor karya atau kinerja, tetapi juga untuk 
3522 Pengembangan Tes Kinerja pada Materi Teks Negosiasi dan Teks Debat Mata Pelajaran Indonesia Berbasis Konteks Budaya Lokal Sumatera Barat - Wilda Fathia

DOI : https://doi.org/10.31004/edukatif.v3i6.927

mewujudkan konsep kualitas yang belum tampak sehingga dapat dipedomani oleh siswa. Berdasarkan hal ini, penting dilakukan pengembangan terhadap tes kinerja yang sesuai dengan kebutuhan siswa.

Penelitian pengembangan tes kinerja telah dipraktikkan secara luas. Namun, penelitian tersebut sebagian besar dilaksanakan pada bidang sains baik kimia, fisika, maupun biologi dan mata pelajaran praktikum. Sementara itu, penelitian tentang pengembangan tes kinerja untuk mata pelajaran bahasa Indonesia belum banyak dilakukan. Hasil penelitian sebelumnya menunjukkan bahwa pengunaan tes kinerja memberikan hasil yang positif pada pembelajaran (Merlis, 2017; Reznani et al., 2021; Bukian, 2017).

Dengan demikian, penting untuk mengembangkan tes kinerja sebagai intrumen pelaksanaan tes menulis bagi siswa. Penelitian ini berbeda dengan penelitian terdahulu, Merlis (2017) melaksanakan penelitian pada pembelajaran Kimia. Kemudian, penelitian yang dilakukan oleh Sukmawa et al., (2019), mengembangkan instrumen tes kinerja pada pembelajaran Fisika. Selanjutnya, tes kinerja juga sering dikembangkan pada sekolah kejuruan, seperti penelitian yang dilakukan Multin et al., (2019) bahwa tes kinerja membantu siswa dalam pelaksanaan praktik memasang sistem penerangan dan wiring kelistrikan.

Berdasarkan penelitian-penelitian tersebut, maka penting dilaksanakan pengembangan tes kinerja untuk bidang bahasa Indonesia terutama dalam pembelajaran menulis. Selain itu, penelitian ini relevan dengan penelitian yang dilaksanakan Bukian (2017) yaitu pengembangan rubrik penilaian kinerja keterampilan berbicara pada pembelajaran bahasa Indonesia. Perbedaan penelitian ini dengan penelitian tersebut yaitu pada aspek keterampilan menulis. Penelitian ini berfokus pada pengembangan tes kinerja berbasis budaya lokal untuk menulis materi teks negosiasi dan teks debat sedangkan penelitian tersebut pada aspek keterampilan berbicara.

Penelitian ini membahas pengembangan tes kinerja pada pembelajaran bahasa Indonesia. Selain itu, penelitian ini didukung oleh penelitian yang dilaksanakan oleh (Reznani et al., 2021) bahwa pengembangan bahan ajar berbasis kearifan lokal berpengaruh dan dapat meningkatkan keterampilan menyimak mahasiswa. Namun, penelitian ini dilaksanakan untuk pengembangan tes kinerja berbasis budaya lokal Sumatera Barat.

Penilaian kinerja mewajibkan siswa menunjukkan pengetahuan, keterampilan, dan kompetensinya dengan aksi (berbuat) berupa produk atau proses. Perbuatan yang terkait dengan berbahasa seperti membuat laporan, mewawancarai, berdebat, menulis cerita (bergambar), dan membaca keras-keras merupakan bentuk penilaian kinerja (Atmazaki, 2013:68). Tes kinerja merupakan salah satu jenis tes yang digunakan untuk mengukur keterampilan siswa. Menurut Anwar, (2009:89), penilaian kinerja mengacu pada upaya melakukan sesuatu (performance is doing) yang mempraktikkan pengalaman tertentu, sehingga prosesnya dapat dikontrol. Penilaian berbasis kinerja menuntut siswa untuk menampilkan suatu tindakan berdasarkan pengetahuannya (Brown dalam Atmazaki, 2013:68). Tes kinerja selalu melibatkan penilaian terhadap perilaku atau suatu produk. Tes kinerja yang absah dilandasi oleh sebuah analisis yang terperinci dan lengkat terhadap keterampilan yang dibutuhkan bagi perilaku tertentu maupun karakteristik yang diinginkan dari suatu produk. Jika suatu perilaku (atau produk akhir) telah selesai dianalisis untuk menetapkan karakteristik esensial dari suatu kinerja yang bernilai, langkah selanjutnya adalah pembuatan skala penilaian untuk mendukung evaluasi akhir (Basuki dan Hariyanto, 2014:52).

Tes kinerja yang digunakan dalam aktivitas pembelajaran dapat dikembangkan dengan berbasis budaya lokal (Wijiningsih et al., 2017). Pembelajaran berbasis budaya lokal merupakan salah satu strategi dalam menciptakan pengalaman belajar yang baik bagi siswa (Susrawan \& Erawan, 2017). Azizah (2019) juga melakukan penelitian pengembangan buku suplemen bahasa Indonesia berbasis budaya lokal untuk melestarikan kebudayaan kepada siswa. Mengintegrasikan pembelajaran atau tes berbasis budaya lokal dalam aktivitas pembelajaran merupakan upaya untuk melestarikan budaya itu sendiri (Kharisma \& Arvianto, 2019).

Kemudian, dalam sebuah tes kinerja juga perlu dilengkapi dengan rubrik penilaian. Menurut Atmazaki (2013:82), rubrik adalah dokumen yang mengartikulasikan harapan terhadap tugas-tugas yang dilengkapi dengan daftar kriteria dan menggambarkan tingkat kualitas mulai dari sangat baik sampai sangat jelek. Rubrik 
3523 Pengembangan Tes Kinerja pada Materi Teks Negosiasi dan Teks Debat Mata Pelajaran Indonesia Berbasis Konteks Budaya Lokal Sumatera Barat - Wilda Fathia

DOI : https://doi.org/10.31004/edukatif.v3i6.927

dapat juga dinyatakan sebagai ringkasan yang eksplisi tentang kriteria untuk menilai karya siswa, ditambah dengan tingkatan prestasi potensial untuk setiap kriteria.

Borgioli (dalam Atmazaki, 2013:84), mengemukakan beberapa prinsip berkaitan dengan pengembangan dan penggunaan rubrik. Pertama, rubrik digunakan untuk menentukan kualitas karya. Karya merupakan istilah umum yang menggambarkan produk yang dibuat siswa, yaitu kinerja yang memperlihatkan proses melaksanakan sebuah tugas. Di dalam rubrik biasanya digunakan kata-kata seperti baik, cukup, dan sangat. Kedua, rubrik tidak dimaksudkan untuk menyekor semua tugas-tugas penilaian. Secara umum, rubrik hanya digunakan untuk tugas-tugas otentik atau kinerja. Ketiga, tujuan membuat rubrik tidak saja untuk meyekor karya atau kinerja, tetapi juga untuk mewujudkan konsep kualitas yang belum tampak sehingga dapat dipedomani oleh siswa. Keempat, kualitas rubrik merupakan hasil dari mendefinisikan dan mengomunikasikan harapan. Kelima, rubrik merupakan alat bagi siswa untuk merefleksi dan kemudian meningkatkan kualitas karya mereka. Keenam, tujuan membuat rubrik bukanlah untuk menahan kreativitas siswa atau untuk mempermalukan mereka yang belum mencapai tungkat yang lebih baik. Ketujuh, pada dasarnya rubrik berkaitan dengan kualitas.

Berdasarkan pemaparan di atas, permasalahan pengembangan tes kinerja berbasis budaya lokal untuk siswa SMA penting untuk ditindaklanjuti. Hal ini dikarenakan siswa perlu diberikan sebuah pemahaman awal atau konteks yang menarik dan dekat dengan dunia siswa. Misalnya konteks yang berkaitan dengan budaya lokal Sumatera Barat. Selain itu, guru perlu menggunakan sebuah rubrik penilaian yang tepat untuk setiap tes keterampilan. Rubrik ini membantu guru untuk dapat menilai secara objektif. Kemudian, tujuan penelitian ini adalah untuk menjelaskan desain pengembangan tes kinerja pada mata pelajaran bahasa Indonesia berbasis konteks budaya lokal. Artikel ini berfokus pada pengembangan tes kinerja untuk keterampilan menulis teks negosiasi dan teks debat.

\section{METODE PENELITIAN}

Jenis penelitian yang digunakan dalam penelitian ini adalah penelitian pengembangan (research development) untuk menghasilkan suatu produk yaitu tes kinerja untuk teks negosiasi dan teks debat. Sugiyono (2010:297) menyatakan bahwa penelitian pengembangan (research devolopment) adalah metode penelitian yang digunakan untuk menghasilkan produk tertentu dan menguji keefektifan produk tersebut. Proses pengembangan tes kinerja dilakukan berdasarkan model pengembangan yang diusulkan Ploum (1997). Proses pengembangan dilakukan dengan 3 tahap, yaitu (a) prelimenary phase, (b) prototyping phase, dan (c) assesment phase. Pada tahap prelimenary phase dilakukan wawancara dengan guru. Selanjutnya, pada tahap prototyping phase dilakukan pengembangan tes kinerja, validasi sendiri, validasi perorangan, dan validasi ahli. Selanjutnya, pada tahap assesment phase tes tersebut diujicobakan dan dilihat kepraktisan tes. Selanjutnya dilakukan wawancara dengan guru berdasarkan tes yang di ujicobakan. Tes kinerja yang dinyatakan valid selanjutnya dilakukan uji coba terbatas kepada siswa kelas X SMA N 7 Padang untuk melihat praktikalitas tes kinerja. Kemudian, subjek penelitian adalah siswa kelas X SMA Negeri 7 Padang. Teknik analisis data yang digunakan adalah teknik analisis data deskriptif. Teknik analisis deskriptif dilakukan dengan menggunakan statistik deskriptif.

\section{HASIL DAN PEMBAHASAN PENELITIAN}

Pada bagian ini dipaparkan hasil dan pembahasan penelitian tentang pengembangan tes kinerja dan rubrik penelitian teks negosiasi dan teks debat untuk siswa SMA kelas X. Penjabaran hasil temuan tersebut, yaitu sebagai berikut ini. 
3524 Pengembangan Tes Kinerja pada Materi Teks Negosiasi dan Teks Debat Mata Pelajaran Indonesia Berbasis Konteks Budaya Lokal Sumatera Barat - Wilda Fathia

DOI : https://doi.org/10.31004/edukatif.v3i6.927

\section{Tahap Prelimenary Phase}

Pada tahap prelimenary investigation dilakukan wawancara untuk mendefinikan masalah yang terjadi dalam proses pembelajaran (Rochmad, 2012). Secara umum, hasil analisis awal dapat diringkas sebagai berikut. Pertama, bersasarkan wawancara dengan guru bahasa Indonesia dapat disimpulkan bahwa penting untuk mengembangkan tes kinerja berbasis konteks budaya lokal untuk siswa SMA. Kedua, keterampilan berbahasa Indonesia siswa SMA Negeri 7 Padang tergolong sangat baik. Hal ini sesuai dengan prestasi yang diperoleh oleh siswa, setiap ada lomba menulis cerpen, puisi, dan artikel, mereka selalu meraih peringkat I atau II. Beberapa prestasi siswa di antaranya meraih juara II lomba keterampilan menulis se-Indonesia yang diadakan oleh kedutaan Amerika, kemudian juara II menulis puisi tingkat Sumatera Barat, dan juara II menulis artikel tingkat Sumatera Barat. Kedua, soal-soal yang ada di dalam buku siswa sudah terkait dengan kehidupan siswa. Kemudian, guru-guru di SMA Negeri 7 Padang tidak menggunakan LKS, karena tidak diperbolehkan oleh pemerintah. Jadi, guru menggunakan buku teks yang dikeluarkan oleh pemerintah, sehingga soal-soal yang diberikan kepada siswa juga disesuaikan dengan buku siswa (buku siswa yang diterbitkan Kemendikbud). Ketiga, tingkat kesulitan soal yang ada dalam buku siswa tidak terlalu sulit, karena siswa dapat mengerjakan soal-soal tersebut dengan baik. Selain itu, soal-soal tersebut membantu siswa dalam mengerjakan tugas atau latihan. Hal ini dapat dilihat dari nilai siswa. Secara umum, siswa memperoleh hasil belajar yang bagus. Siswa juga sangat bersemangat ketika belajar bahasa Indonesia.

Keempat, soal yang diberikan sudah valid dan reliabel. Kelima, soal-soal bahasa Indonesia yang digunakan sudah sesuai dengan konteks. Keenam, guru sudah terbiasa membuat soal-soal, tetapi soal yang dibuat belum terdapat konteks, instruksi, dan rubrik penilain. Secara umum, guru belum terbiasa untuk membuat tes kinerja. Penilaian kinerja didapat oleh guru dari mahasiswa yang praktik lapangan (PL) di sekolah tersebut. Sebelumnya, guru belum menggunakan tes kinerja untuk mengukur keterampilan menulis siswa. Ketujuh, guru belum terbiasa menggunakan rubrik untuk untuk penilain tes kinerja. Guru lebih sering menggunakan penyekoran. Misalnya, apabila ada lima soal maka nilai maksimal tersebut dibagi 5. Untuk soal yang sulit diberikan skor 25, sedangkan untuk soal yang tidak terlalu sulit diberi skor 10. Kedelapan, penilaian tes kinerja yang diberikan kepada siswa sudah sesuai dengan KI dan KD. Kesembilan, ketika mahasiswa PL menerapkan tes kinerja yang terdapat konteks, instruksi dan rubrik kepada siswa, tidak ada kendala yang dialami. Tes kinerja tersebut lebih membantu siswa dalam mengerjakan latihan. Kesepuluh, format penilaian tes kinerja dapat membantu dalam mengukur keterampilan berbahasa Indonesia siswa. Kesebelas, guru sangat mendukung penilaian tes kinerja yang lengkap, karena lebih terperinci dan lebih terarah. Penilaian tes kinerja ini dapat membantu guru dalam melakukan penilaian.

Penjabaran pada fase ini sejalan dengan penelitian yang dilakukan Arianatasari (2015) bahwa pada tahap ini dilakukan analisis informasi kepada guru. Berdasarkan tahapan tersebut diperoleh berbagai informasi untuk tindak lanjut penyusunan tes kinerja berbasis konteks budaya lokal untuk penulisan teks negosiasi dan teks debat.

\section{Tahap Prototyping Phase atau Fase Desain}

Tahap Prototyping Phase ini terdiri dari dua tahapan, yaitu tahap spesifikasi model dan Self Evaluation. Pada tahap spesifikasi model dilakukan perancangan tes kinerja dan rubrik penilaian. Tes kinerja yang dirancang adalah untuk mengukur keterampilan menulis teks negosiasi dan teks debat. Hal tersebut tertcantum pada KD 4. 11 dan 4. 13. KD. 11 yaitu mengonstruksikan teks negosiasi dengan memerhatikan isi, struktur (orientasi, pengajuan, penawaran, persetujuan, dan penutup) dan kebahasaan. Kemudian, KD 4. 13, yaitu mengonstruksi permasalahan/isu, sudut pandang dan argumen beberapa pihak dan simpulan dari debat secara lisan untuk mengajukan esensi dari debat.

Tes kinerja dirancang memiliki tiga aspek, yaitu konteks, instruksi, dan rubrik penilaian. Konteks berisi penjabaran umum untuk membuka skemata siswa terkait tes yang akan dilakukan. Kemudian, instuksi berisi langkah-langkah dan pedoman bagi siswa untuk mengerjakan tes kinerja. Selanjutnya, rubrik penilaian terdiri 
3525 Pengembangan Tes Kinerja pada Materi Teks Negosiasi dan Teks Debat Mata Pelajaran Indonesia Berbasis Konteks Budaya Lokal Sumatera Barat - Wilda Fathia

DOI : https://doi.org/10.31004/edukatif.v3i6.927

atas aspek penilaian dan tingkat kinerja yang dijabarkan melalui beberapa deskriptor. Hal ini berguna untuk memudahkan siswa dalam mengerjakan tes kinerja. Selain itu, rubrik penilaian juga bertujuan agar siswa mengetahui aspek apa saja yang akan dinilai dari tes yang mereka kerjakan, sehingga siswa dapat mengerjakan latihan dengan lebih baik dan cermat.

Tahap berikutnya, yaitu self evaluation dilakukan untuk memeriksa kembali kesesuaian format tes kinerja dengan teori penilaian kinerja. Terdapat enam aspek yang diperhatikan dalam tahap self-evaluation. Penjabaran setiap aspek, yaitu sebagai berikut.

Pertama, tes kinerja yang dirancang telah sesuai dengan struktur penilaian kinerja, yaitu konteks, instruksi, dan rubrik penilaian. Kedua, konteks tes kinerja sudah terkait dengan budaya lokal Sumatera Barat. Ketiga, tes kinerja telah memiliki instruksi tes kinerja yang lengkap dan terperinci. Keempat, rubrik tes kinerja lengkap, terdapat kriteria, bobot, tingkat kinerja, deskriptor, dan skor. Kelima, bahasa pada konteks, instruksi, dan rubrik penilaian mudah dipahami dan tidak ada kesalahan pengetikan. Keenam, gambar, tabel, atau grafik (jika ada) dirancang dengan penempatan yang tepat.

\section{Lembar Validasi Ahli}

Setelah tahap self evaluation selesai maka dilakukan tahap validasi yang dilakukan oleh ahli. Kegiatan yang dilakukan pada tahap ini adalah uji validitas. Uji validitas tersebut dilakukan untuk mengetahui tingkat kevalidan tes kinerja mata pelajaran bahasa Indonesia SMA menggunakan konteks budaya lokal Sumatera Barat. Validasi ini dilihat dari tiga aspek, yaitu isi, konstruk, dan bahasa. Data validasi dikumpulkan dalam bentuk angket. Kemudian, data yang diberikan akan digunakan untuk mengetahui kevalidan tes kinerja bahasa Indonesia siswa di kelas X SMA Negeri 7 Padang.

Secara keseluruhan, lembar validasi ini terdiri atas 17 butir pernyataan, dengan pembagian, 4 butir pernyataan untuk aspek isi, 5 butir pernyataan untuk aspek konstruk, dan 8 butir pernyataan untuk aspek bahasa. Kemudian, alternatif jawaban yang disedikan untuk angket validasi ini menggunakan skala likert dengan empat alternatif jawaban, yaitu sangat tidak setuju (STS) dengan skor 1, tidak setuju (TS) dengan skor 2, setuju (S) dengan skor 3, dan sangat setuju (SS) dengan skor 4. Berikut penjabaran hasil validasi tes kinerja.

\section{Hasil Validasi Tes Kinerja Aspek Isi dan Konstruk}

Validasi tes kinerja ini dilakukan untuk mengetahui kevalidan tes kinerja yang akan digunakan sebagai tes kimerja untuk mendeskripsikan kemampuan berbahasa siswa di kelas X SMA. Validasi tes kinerja untuk aspek isi dan konstruk dilakukan oleh lima belas orang validator. Berdasarkan hasil analisis terhadap jawaban validator pada lembar validasi, diperoleh hasil seperti tertera pada tabel berikut ini.

Tabel 1. Validitas Tes Kinerja oleh Pakar untuk Aspek Isi

\begin{tabular}{ccccc}
\hline No & Aspek yang dinilai & Pemerolehan skor & $\begin{array}{c}\text { Nilai } \\
\text { Validitas }\end{array}$ & Kategori \\
\hline 1 & Isi & 205 & $85,44 \%$ & Sangat Valid \\
\hline 2 & Konstruk & 269 & $89,65 \%$ & Sangat Valid \\
\hline $\begin{array}{c}\text { Nilai validitas secara } \\
\text { keseluruhan }\end{array}$ & $\mathbf{4 7 4}$ & $\mathbf{8 7 , 5 4 \%}$ & Sangat Valid \\
\hline
\end{tabular}

Validitas untuk aspek kelayakan isi dan konstruk diperoleh dari 9 butir pernyataan. Berdasarkan analisis yang dilakukan, diperoleh validitas tes kinerja untuk aspek kelayakan isi sebesar 85,44\%. Artinya, tes kinerja untuk aspek kelayakan isi tergolong sangat valid. Kemudian, validasi untuk aspek kelayakan konstruk diperoleh sebesar $89,65 \%$, dengan kategori sangat valid. Selanjutnya, secara keseluruhan nilai validitas tes kinerja untuk aspek isi adaalah $87,54 \%$, dengan kategori sangat valid.

Hasil ini sejalan dengan penelitian yang dilakukan oleh Rahmawan et al. (2016) bahwa di tahapan ini validitas terhadap produk yang dikembangkan perlu untuk dilakukan. Kemudian, penelitian ini juga sejalan dengan penelitian yang dilakukan (Reznani et al., 2021) bahwa pengembangan bahan ajar berbasis kearifan 
3526 Pengembangan Tes Kinerja pada Materi Teks Negosiasi dan Teks Debat Mata Pelajaran Indonesia Berbasis Konteks Budaya Lokal Sumatera Barat - Wilda Fathia

DOI : https://doi.org/10.31004/edukatif.v3i6.927

lokal dapat digunakan dalam proses pembelajaran. Pada penelitian ini dimaksudkan pada pengembangan tes kinerja berbasis budaya lokal dan dilengkapi dengan instrumen atau rubril penilaian.

\section{Hasil Validasi Aspek Bahasa}

Uji validasi dilakukan untuk mengukur tingkat kevalidan tes kinerja yang telah dirancang dan dilihat dari aspek bahasa. Proses validasi dilakukan dengan cara mengisi lembar angket validasi yang terdiri atas 8 butir pernyataan. Melalui angket tersebut, validator dapat memberikan penilaian, saran, dan komentar terhadap tes kinerja yang telah dirancang. Tes kinerja ini divalidasi oleh lima belas orang validator. Hasil validasi terhadap tes kinerja yang dirancang, dapat dilihat pada tabel berikut ini.

Tabel 2. Hasil Validasi Tes Kinerja oleh Pakar untuk Aspek Bahasa

\begin{tabular}{ccccc}
\hline No & Aspek yang dinilai & Pemerolehan skor & $\begin{array}{c}\text { Nilai } \\
\text { Validitas }\end{array}$ & Kategori \\
\hline 1 & Bahasa & 395 & $82,28 \%$ & Sangat Valid \\
\hline
\end{tabular}

Validitas untuk aspek kelayakan bahasa diperoleh dari 8 butir pernyataan. Berdasarkan analisis yang dilakukan, diperoleh validitas tes kinerja untuk aspek kelayakan bahasa sebesar 82,28 \%. Artinya, tes kinerja untuk aspek kelayakan bahasa tergolong sangat valid.

\section{Lembar Validasi One to One}

Validasi ini dilakukan dengan melakukan wawancara untuk tahap evaluasi perorangan (one to one). Wawancara ini dilakukan untuk memeroleh gambaran dari siswa tentang penggunaan tes kinerja bahasa Indonesia untuk teks negosiasi dan teks debat. Wawancara dilakukan dengan seorang siswa kelas X SMA Negeri 7 Padang, yaitu Shafira Dinil Fitri. Wawancara ini terdiri atas 13 butir pertanyaan.

Berdasarkan hasil wawancara dengan siswa pada tahap validasi one to one, diperoleh informasi sebagai berikut. Pertama, siswa pernah diberikan tes untuk mengukur kemampuan dalam bentuk tes kinerja. Kedua, sebelumnya tes kinerja yang diberikan dalam bentuk latihan. Namun, pada semester 1 ini, siswa mengerjakan tes kinerja yang telah memiliki konteks dan instruksi. Hal tersebut dilakukan ketika belajar dengan guru PL. Ketiga, siswa memahami petunjuk pengerjaan tes kinerja. Keempat, siswa memahami istilah-istilah yang terdapat pada tes kinerja teks negosiasi dan teks debat. Kelima, siswa memahami setiap pernyataan yang terdapat dalam tes kinerja. Keenam, konteks dalam tes kinerja dapat membantu dan memudahkan siswa dalam mengerjakan tugas yang diberikan. Hal tersebut, karena konteks yang diberikan dapat membuka atau menggiring pemikiran siswa untuk menulis teks negosiasi. Ketujuh, siswa cukup dapat menganalisis permasalahan yang terdapat dalam konteks yang diberikan. Kedelapan, siswa belum mengetahui apa yang dimaksud dengan rubrik penilaian pada tes kinerja. Kesembilan, siswa pernah diberitahu oleh guru mengenai rubrik penilaian. Akan tetapi penilaian tersebut hanya disampaikan secara lisan. Kesepuluh, siswa belum pernah melihat rubrik penilaian yang tertera pada tes kinerja teks negosiasi. Kesebelas, siswa cukup memahami cara penilaian yang terdapat pada rubrik yang terlampir pada tes kinerja. Keduabelas, siswa merasa mampu menyelesaikan tes kinerja dengan waktu yang telah ditentukan. Ketigabelas, tes kinerja dapat membantu siswa dalam mengerjakan tugas.

\section{Tahap Assesment Phase}

\section{Angket Praktikalitas}

Setelah tes kinerja ini dinyatakan sangat valid oleh validor, kemudian tes ini diberikan kepada siswa untuk mengetahui kepraktisan tes kinerja keterampilan berbahasa Indonesia untuk teks negosiasi dan teks debat tingkat SMA. Untuk mengetahui kepraktisan tes kinerja yang telah dibuat, maka digunakan angket praktikalitas. Secara keseluruhan, lembar validasi ini terdiri atas 11 butir pernyataan. Kemudian, alternatif jawaban yang disedikan untuk angket validasi ini menggunakan skala likert dengan empat alternatif jawaban, yaitu sangat tidak setuju (STS) dengan skor 1, tidak setuju (TS) dengan skor 2, setuju (S) dengan skor 3, dan sangat setuju (SS) dengan skor 4. Hasil pengisian angket kepraktikisan tes kinerja keterampilan berbahasa Indonesia untuk siswa SMA dapat dilihat pada tabel 3 berikut. 
3527 Pengembangan Tes Kinerja pada Materi Teks Negosiasi dan Teks Debat Mata Pelajaran Indonesia Berbasis Konteks Budaya Lokal Sumatera Barat - Wilda Fathia

$D O I$ : https://doi.org/10.31004/edukatif.v3i6.927

Tabel 3. Praktikalitas Tes Kinerja Teks Negosiasi dan Teks Debat

\begin{tabular}{ccccc}
\hline No & Aspek yang dinilai & Pemerolehan skor & $\begin{array}{c}\text { Nilai } \\
\text { Praktikalitas }\end{array}$ & Kategori \\
\hline 1 & Kepraktisan & 331 & $77,25 \%$ & Praktis \\
\hline
\end{tabular}

Berdasarkan analisis yang dilakukan untuk aspek praktikalitas diperoleh hasil praktikalitas 77,25\%. Artinya, tes kinerja teks negosiasi dan teks debat berkategori praktis.

\section{Pedoman Wawancara}

Pada tahap ini, dilakukan wawancara dengan guru dan siswa pada uji lapangan. Dalam hal ini wawancara dilakukan dengan salah seorang guru mata pelajaran bahasa Indonesia di SMA Negeri 7 Padang, yaitu ibu Aniswati M., S.Pd. Kemudian, wawancara dengan siswa dilakukan pada dua orang siswa, yaitu Dea Ananda dan Salsabila Putri Ariska. Terdapat 10 butir pertanyaan yang diajukan kepada narasumber.

\section{Wawancara dengan Guru pada Uji Lapangan}

Berdasarkan wawancara, diperoleh informasi sebagai berikut. Pertama, soal-soal keterampilan berbahasa Indonesia menggunakan budaya Sumatera Barat sangat bagus dan sebaiknya memang perlu digunakan untuuk tugas atau latihan siswa. Kedua, soal-soal memberikan gambaran manfaat mempelajari bahasa Indonesia dalam kehidupan sehari-hari. Ketiga, guru merasa sangat ingin mencoba mengembangkan soal-soal bahasa Indonesia menggunakan konteks yang telah dijelaskan sebelumnya. Keempat, soal-soal bahasa Indonesia yang menggunakan konteks dapat memberikan kemudahan bagi siswa dalam mengerjakan tes. Kelima, guru tertarik mencoba untuk mengembangkan soal-soal bahasa Indonesia menggunakan instruksi lengkap dan terperinci. Keenam, soal-soal bahasa Indonesia yang menggunakan instruksi lengkap dan terperinci akan memberikan kemudahan bagi siswa dalam mengerjakan tes. Ketujuh, rubrik penilaian sangat perlu dilampirkan dalam tes. Kedelapan, rubrik penilaian dapat memaksimalkan kinerja siswa dalam mengerjakan tes. Kesembilan, rubrik penilaian dapat menilai secara keseluruhan aspek penilaian yang diujikan pada siswa. Kesepuluh, rubrik penilaian dapat memberikan penilaian yang sama jika digunakan oleh penilai yang berbeda.

\section{Wawancara dengan Siswa pada Uji Lapangan}

Wawancara dengan siswa dilakukan pada saat uji lapangan di SMA Negeri 7 Padang. Berikut hasil wawancara yang dilakukan dengan siswa. Pertama, wawancara yang dilakukan dengan Dea Ananda. Berdasarkan hasil wawancara diperoleh informasi sebagai berikut. 1) Soal-soal bahasa Indonesia yang memasukkan budaya Sumatera Barat sangat bagus karena sesuai dengan kebudayaan maysarakat Minangkabau, sehingga siswa mengetahui kebudayaan di Sumatera Barat. 2) Soal-soal yang diberikan memberikan manfaat dalam kehidupan sehari-hari. 3) Siswa tertarik untuk mengerjakan soal-soal tersebut menggunakan konteks yang berbeda. 4) Konteks yang terdapat dalam tes dapat membantu narasumber mengerjakan tes. 5) Instruksi yang digunakan dalam tes mudah dipahami. 6) Siswa cukup tertarik terhadap tes yang memiliki instruksi yang spesifik.7) Siswa cukup tertarik jika dalam instruksi ditambahkan sebuah ilustrasi sebagai batasan untuk mengerjakan tes. 8) Siswa menganggap bahwa rubrik penilaian tidak perlu dilampirkan dalam soal, cukup dijelaskan oleh guru. 9) Rubrik penilaian mampu memaksimalkan tes yang ditulis. 10) Siswa cukup dapat menilai sendiri tes yang ditulis dengan menggunakan rubrik penilaian.

Selanjutnya, wawancara yang dilakukan dengan Salsabila Putri Ariska. Berdasarkan hasil wawancara, diperoleh informasi sebagai berikut. 1) Soal-soal bahasa Indonesia yang memasukkan budaya Sumatera Barat cukup bagus karena memberikan pengetahuan kepada siswa tentang budaya yang ada di lingkungannya. 2) Soal-soal yang diberikan memberikan manfaat dalam kehidupan sehari-hari. 3) Siswa cukup tertarik untuk mengerjakan soal-soal tersebut menggunakan konteks yang berbeda. 4) Konteks yang terdapat dalam tes dapat membantu narasumber mengerjakan tes. 5) Instruksi yang digunakan dalam tes mudah dipahami. 6) Siswa cukup tertarik terhadap tes yang memiliki instruksi yang spesifik. 7) Siswa cukup tertarik jika dalam instruksi ditambahkan sebuah ilustrasi sebagai batasan untuk mengerjakan tes. 8) Siswa menganggap bahwa rubrik 
3528 Pengembangan Tes Kinerja pada Materi Teks Negosiasi dan Teks Debat Mata Pelajaran Indonesia Berbasis Konteks Budaya Lokal Sumatera Barat - Wilda Fathia

DOI : https://doi.org/10.31004/edukatif.v3i6.927

penilaian perlu dilampirkan dalam soal. 9) Rubrik penilaian mampu memaksimalkan tes yang ditulis. 10) Siswa merasa dapat menilai sendiri tes yang ditulis dengan menggunakan rubrik penilaian yang diberikan.

Berdasarkan pemaparan pada bagian hasil dan pembahasan dapat disimpulkan bahwa dari penilaian tiga tahapan tersebut, validitas tes kinerja untuk aspek isi adalah 87,54\%, dengan kategori sangat valid. Kemudian, untuk aspek kebahasaan validitas tes kinerja untuk aspek bahasa adalah 82,28 dengan kategori sangat valid. Tes kinerja menulis teks negosiasi dan debat berkategori praktis, dengan hasil 77,25\%.

Temuan penelitian ini sejalan dengan penelitian yang dilakukan oleh (Bukian, 2017) bahwa tes kinerja yang valid, dan praktis dapat digunakan untuk mempermudah dan membantu siswa dalam mengerjakan tes keterampilan. Pada penelitian ini, dikhususkan dalam hal menulis (teks negosiasi dan teks debat). Selain itu, penelitian ini juga diperkuat oleh penelitian yang dilakukan (Rahmawan et al., 2016) tentang penyusunan instrumen tes kinerja. Tes kinerja dapat meningkatkan kemampuan bernyanyi siswa berbasis android. Perbedaan hasil penelitian tersebut terletak pada materi pembelajaran. Penelitian ini memberikan implikasi positif pada pembelajaran keterampilan menulis teks negosiasi dan teks debat. Secara tidak langsung, hasil penelitian ini memberikan kontribusi yang positif dalam pembelajaran bahasa Indonesia, khususnya pada tahapan evaluasi pembelajaran.

Kemudian, hasil penelitian juga menunjukkan bahwa penggunaan tes kinerja yang valid dan praktis dapat mengukur keterampilan peserta didik di bidang menulis. Hal ini sesuai dengan penelitan yang dilakukan (Sa'idah et al., 2017) bahwa penilaian ini dapat mengukur kompetensi siswa secara nyata dan teintegrasi dengan penilaian kognitif, afektif, dan psikomotor. Kemudian, terkait dengan temuan penelitan pengembangan tes kinerja berbasis budaya lokal bahwa hal tersebut memberikan pengetahuan dan ketertarikan bagi siswa dalam menulis. Penggunaan konteks budaya lokal ini dapat melestasikan kearifan lokal melalui pembelajaran. Temuan ini sejalan dengan penelitian yang dilakukan Kharisma \& Arvianto, (2019) dan Azizah (2019) bahwa pengembangan modul pembelajaran berbasis kearifan lokal layak untuk diimplementasikan pada pembelajaran. Kegiatan pembelajaran yang memuat budaya lokal akan membuat anak lebih mudah mempelajari budaya di lingkungan mereka.

Selain hal itu, temuan penelitian ini penggunaan konteks dalam tes kinerja dapat membantu siswa memahami soal dan lebih mudah untuk mengerjakan tes, terutama keterampilan menulis. Selain itu, tes kinerja yang disertai dengan rubrik penilaian juga membantu siswa dalam menulis. Hal tersebut membuat siswa paham poin apa saja yang dinilai oleh guru dan memperhatikan faktor-faktor yang terdapat pada indikator penilaian. Dengan memperhatikan hal tersebut membuat siswa lebih teliti dalam menulis. Hasil penelitian ini mendukung pernyataan yang disampaikan (Atmazaki, 2013) bahwa rubrik penilaian dapat digunakan sebagai alat bagi siswa untuk merefleksi dan kemudian meningkatkan kualitas karya mereka. Dengan demikian, penggunaan tes kinerja berbasis budaya lokal yang disertai dengan konteks dan rubrik penilaian menjadi salah satu instrumen yang dapat digunakan oleh guru pengampu mata pelajaran bahasa Indonesia. Tes tersebut terbukti dapat membantu siswa mengerjakan tes dengan baik. Namun, terdapat keterbatasan dalam temuan ini bahwa pembuatan instrumen tes kinerja disertai rubrik penilaian memerlukan waktu yang cukup lama. Sebab instrumen tersebut harus divalidasi terlebih dahulu. Faktor lain karena belum banyak contoh mengenai tes kinerja untuk pembelajaran bahasa. Namun, dengan adanya penelitian ini, hasil penelitian diharapkan dapat dijadikan landasan dalam mengembangkan tes sejenis.

Selain hal tersebut, penelitian ini juga menjadi bagian dari perkembangan keilmuan dalam pembelajaran bahasa Indonesia. Sebab, umumnya selama ini tes kinerja masih jarang digunakan dalam pembelajaran bahasa. Tes jenis ini lebih sering digunakan pada pembelajaran sains. Melalui penelitian ini, pendidik dapat mengembangkan tes kinerja untuk materi pembelajaran yang lain dan disesuaikan dengan konteks budaya lokal di daerah masing-masing. Hasil temuan ini juga memberi makna bahwa penilaian yang objektif dapat dilakukan jika pendidik menilai berdasarkan rubrik penilaian yang telah divalidasi, sehingga siapapun yang memberi nilai, hasilnya akan tetap sama. 
3529 Pengembangan Tes Kinerja pada Materi Teks Negosiasi dan Teks Debat Mata Pelajaran Indonesia Berbasis Konteks Budaya Lokal Sumatera Barat - Wilda Fathia

DOI : https://doi.org/10.31004/edukatif.v3i6.927

\section{KESIMPULAN}

Berdasarkan pembahasan dalam penelitian, dapat disimpulkan beberapa hal sebagai berikut. Proses pengembangan tes kinerja dikembangkan berdasarkan model Plom. Komponen pada tes kinerja disusun menjadi tiga bagian, yaitu konteks, instruksi, dan rubrik penilaian. Kemudian, pada tahap pengembangan teks kinerja, diperoleh hasil berikut. Pertama, tes kinerja menulis teks negosiasi dan teks debat menggunakan konteks budaya Sumatera Barat siswa kelas X SMA untuk aspek isi validitas tes kinerja untuk aspek isi adalah $87,54 \%$, dengan kategori sangat valid. Kedua, tes kinerja menulis teks negosiasi dan teks debat menggunakan konteks budaya Sumatera Barat siswa kelas X SMA untuk aspek kebahasaan validitas tes kinerja untuk aspek bahasa adalah 82, 28 dengan kategori sangat valid. Ketiga, tes kinerja menulis teks negosiasi dan debat berkategori praktis, dengan hasil 77,25\%.

\section{DAFTAR PUSTAKA}

Ambarsari, P., Bharati, D. A. L., \& Rusilowati, A. (2017). Pengembangan Instrumen Penilaian Unjuk Kerja Pada Reading Aloud Text Recount Siswa SMP Pada Kurikulum 2013. Journal Of Educational Research And Evaluation, 6(1), 10-18.

Anwar, S. (2009). Penilaian Berbasis Kompetensi. UNP Press.

Arianatasari, A. (2015). Penerapan Desain Model Plomp Pada Pengembangan Buku Teks Berbasis Guided Inquiry. 36-40.

Atmazaki. (2013). Penilaian Alternatif Dalam Pembelajaran Bahasa Indonesia. UNP Press.

Azizah, L. N. (2019). Pengembangan Buku Suplemen Bahasa Indonesia Berbasis Budaya Lokal Menggunakan Model CIRC Untuk Siswa Sekolah Dasar. 01(02).

Bukian, P. A. (2017). Pengembangan Instrumen Penilaian Kinerja Keterampilan Berbicara Dalam Pembelajaran Bahasa Indonesia. 15(2), 133-145.

Cicilia, Y., \& Nursalim, N. (2019). Gaya Dan Strategi Belajar Bahasa. Edukatif: Jurnal Ilmu Pendidikan, 1(3), 138-149. Https://Doi.Org/10.31004/Edukatif.V1i3.30

Kemendikbud. (2015a). Bahasa Indonesi. Kemendikbud.

Kemendikbud. (2015b). Bahasa Indonesia SMA/MA/SMK/MAK Kelas X. Kemendikbud.

Kharisma, G. I., \& Arvianto, F. (2019). Pengembangan Aplikasi Android Berbentuk Education Games Berbasis Budaya Lokal Untuk Keterampilan Membaca Permulaan Bagi Siswa Kelas 1 SD/MI. Premiere Educandum: Jurnal Pendidikan Dasar Dan Pembelajaran, 9(2), 203. Https://Doi.Org/10.25273/Pe.V9i2.5234

Kurniawati, D., \& Mawardi. (2021). Pengembangan Instrumen Penilaian Sikap Gotong Royong Dalam Pembelajaran Tematik Di Sekolah Dasar. Edukatif: Jurnal Ilmu Pendidikan, 3(3), 640-648. Https://Doi.Org/10.31004/Edukatif.V3i3.387

Mahsun. (2014). Teks Dalam Pembelajaran Bahasa Indonesia Kurikulum 2013. Raja Grafindo Persada.

Merlis, M. (2017). Pengembangan Butir Soal Tes Kinerja Pada Mata Pelajaran Kimia SMA Berdasarkan Keterampilan Proses Sains. Prosiding Seminar Nasional Pendidikan IPA, 276-296.

Multin, H. A., Munawar, W., \& Noor, A. A. M. (2019). Penyusunan Dan Analisis Tes Kinerja (Performance Test) Pada Kompetensi Praktik Memasang Sistem Penerangan Dan Wiring Kelistrikan Di Smk. Journal Of Mechanical Engineering Education, 5(2), 176. Https://Doi.Org/10.17509/Jmee.V5i2.15185

Plomp, T. (1997). Educational Design: Introduction From Tjeerd Plomp (Eds). Faculty Of Educational Science And Technology, University Of Twente.

Rahmawan, E. F., Sumaryanto, T., \& Supriyadi, S. (2016). Pengembangan Instrumen Penilaian Kinerja 
3530 Pengembangan Tes Kinerja pada Materi Teks Negosiasi dan Teks Debat Mata Pelajaran Indonesia Berbasis Konteks Budaya Lokal Sumatera Barat - Wilda Fathia

DOI : https://doi.org/10.31004/edukatif.v3i6.927

Kemampuan Bernyanyi Berbasis Android. Journal Of Educational Research And Evaluation, 5(1), 8189. Https://Doi.Org/10.15294/JRER.V5I1.14888

Reznani, N. S., Nurhayati, N., \& Soetopo, S. (2021). Pengembangan Bahan Ajar Mata Kuliah Menyimak Berbasis Kerarifan Lokal. Jurnal Pendidikan Bahasa Dan Sastra, 21(1).

Rochmad. (2012). Desain Model Pengembangan Perangkat Pembelajaran Matematika. Kreano: Jurnal Matematika Kreatif-Inovatif, 3(1), 59-72. Https://Doi.Org/10.15294/Kreano.V3i1.2613

Sa'idah, N., Yulistianti, H. D., \& Farida, E. (2017). Efektivitas Penerapan Penilaian Otentik Pembelajaran Bahasa Indonesia Untuk Peningkatan Kinerja Ilmiah Siswa. Jurnal Refleksi Edukatika, 8(1), 1-8.

Sukmawa, O., Rosidin, U., \& Sesunan, F. (2019). Pengembangan Instrumen Asesmen Kinerja (Performance Assessment) Praktikum Pada Mata Pelajaran Fisika Di Sma. Jurnal Pendidikan Fisika, 7(1), 116. Https://Doi.Org/10.24127/Jpf.V7i1.1397

Susrawan, I. N. A., \& Erawan, D. G. B. (2017). Pengembangan Bahan Ajar Bahasa Indonesia Berbasis Budaya Lokal Balidi Kelas Vii Smp Pgri 3 Denpasar. Jurnal Santiaji Pendidikan (JSP), 7(2), 227-238. Https://Doi.Org/10.36733/Jsp.V7i2.71

Tosun, C. (2020). The Predictive Effect Of Some Variables On Fifth And Sixth Grade Students' Scientific Process Skills. Journal of Education In Science, Environment And Health, 6(1), 10-23. Https://Doi.Org/10.21891/Jeseh.657339

Wijiningsih, N., Wahjoedi, W., \& Sumarmi, S. (2017). Pengembangan Bahan Ajar Tematik Berbasis Budaya Lokal. Jurnal Pendidikan: Teori, Penelitian, Dan Pengembangan, 2(8), 1030-1036. Https://Doi.Org/10.17977/JPTPP.V2I8.9760 